\title{
Retinal incorporation and differentiation of mesenchymal stem cells intravitreally injected in the injured retina of rats
}

\author{
Incorporação e diferenciação retiniana de células tronco mesenquimais \\ intravitreas em ratos
}

\author{
Paula Castanheira ${ }^{1}$ \\ Leonardo Torquetti ${ }^{2}$ \\ Marcio Bittar Nehemy ${ }^{3}$ \\ Alfredo Miranda Goes ${ }^{4}$
}

\begin{tabular}{|l|}
\hline ABSTRACT \\
\hline Purpose: To evaluate the pattern of retinal integration and differen- \\
tiation of mesenchymal stem cells (MSCs) injected into the vitreous \\
cavity of rat eyes with retinal injury. Methods: Adult rat retinas were \\
submitted to laser damage followed by transplantation of DAPI- \\
labeled BM-MSCs grafts. To assess the integration and differentiation \\
of BM-MSCs in laser-injured retina, host retinas were evaluated 2.4 \\
and 8 weeks after injury/transplantation. Results: Our results demons- \\
trated that the grafted cells survived in the retina for at least 8 weeks \\
and almost all BM-MSCs migrated and incorporated into the neural \\
retina, specifically in the outer nuclear layer (ONL), inner nuclear \\
layer (INL) and ganglion cell layer (GCL) while a subset of grafted \\
cells were found in the subretinal space posttransplantation. At 8 \\
weeks immunohistochemical analysis with several retinal specific \\
markers revealed that the majority of the grafted cells expressed \\
rhodopsin, a rod photoreceptor marker, followed by parvalbumin, a \\
marker for bipolar and amacrine cells. A few subsets of cells were able \\
to express a glial marker, glial fibrillary acidic protein. However, \\
grafted cells failed to express pan-cytokeratin, a retinal pigment \\
epithelium marker. Conclusions: These results suggest the potential of \\
BM-MSCs to differentiate into retinal neurons. Taken together, these \\
findings might be clinically relevant for future mesenchymal stem cell \\
therapy studies concerning retinal degeneration repair.
\end{tabular}

Keywords: Mesenchymal stem cells/physiology; Cell survival/drug effects; Retinal degeneration; Retina/injuries; Injections; Vitreous body; Rats
Trabalho realizado na Universidade Federal de Minas Gerais - UFMG - Belo Horizonte (MG) - Brazil.

MSc Department of Biochemistry and Immunology, Biological Sciences Institute, Universidade Federal de Minas Gerais - UFMG - Belo Horizonte (MG) - Brazil. MD Department of Ophthalmology, Medicine Faculty, São Geraldo Eye Hospital, UFMG - Belo Horizonte (MG) - Brazil.

PhD Department of Ophthalmology, Medicine Faculty, São Geraldo Eye Hospital, UFMG - Belo Horizonte (MG) - Brazil.

${ }^{4} \mathrm{PhD}$ Department of Biochemistry and Immunology, Biological Sciences Institute, UFMG - Belo Horizonte (MG) - Brazil.

Correspondence to: Alfredo M. Goes. Department of Biochemistry and Immunology - Biological Sciences Institute - Universidade Federal de Minas Gerais - Av. Antonio Carlos, 6627 - ICB, Q4 -167 - Belo Horizonte (MG) Zip Code 31270-901

Disclosure of potential conflicts of interest: The authors indicate no potential conflicts of interest.

Financial Support: This investigation received financial support from the Coordenação de Aperfeiçoamento de Pessoal de Nível Superior (CAPES/Brazil), Fundação de Amparo à Pesquisa do Estado de Minas Gerais (FAPEMIG/Brazil) and Conselho Nacional de Desenvolvimento Científico e Tecnológico ( $\mathrm{CNPq} /$ Brazil). All experiments were performed according to the Ethical Principles in Animal Experimentation (CETEA/UFMG) and approved under the certificate number $3 / 2006$.

Recebido para publicação em 16.12.2007

Última versão recebida em 20.07.2008

Aprovação em 07.08.2008

Nota Editorial: Depois de concluída a análise do artigo sob sigilo editorial e com a anuência do Dr. Haroldo Vieira de Moraes Jr. sobre a divulgação de seu nome como revisor, agradecemos sua participação neste processo.

\section{INTRODUCTION}

There are a number of inherited retinal and retinal-neuronal degenerative diseases that can result in blindness, such as retinitis pigmentosa, agerelated macular degeneration, glaucoma, and related retinal dystrophies. No effective therapies have yet been developed to prevent or reverse the degenerative processes in these disorders. Retinal transplantation has been considered, but effective neural integration and survival of the differentiated cells have not been reported ${ }^{(1)}$.

Over the past few years, the identification and characterization of stem cells has led the potential use of these cells as a promising alternative to cell replacement therapy. The use of stem cells as a therapeutic option might be a practical approach for treating retinal dystrophies and might help to 
restore vision by repopulating the damaged retina and/or by rescuing retinal neurons from further degeneration ${ }^{(2)}$.

From a clinical perspective, mesenchymal stem cells (MSCs) have some potential advantages for retinal transplantation compared to retinal stem cells. Retinal stem cells have been extensively used, but the technical difficulties in obtaining these cells and their limited availability must be overcome prior to the application of these stem cells for human treatment $^{(3)}$. One great advantage of MSCs is that these cells can be directly obtained from the patient by a simple procedure, thereby eliminating the complications associated with immune rejection of allogenic tissue and infectious diseases. The fact that these cells are easily obtained and propagated in large amounts in culture with potential plasticity and selfrenewal capacity also makes them an attractive candidate therapeutic tool for retinal repair by autologous transplantation ${ }^{(4)}$.

In vitro isolation and characterization of MSCs is often based on their adherence, rapid expansion, and expression of specific cell surface antigens, as well as their ability to differentiate into various mesodermal tissues, such as fat, bone, cartilage, and muscle $\mathrm{e}^{(5-10)}$.

Cultured MSCs can be induced in vitro and in vivo to differentiate into non-mesenchymal derivatives such as neural cells, a process called stem cell plasticity ${ }^{(11-13)}$.

Bone marrow mesenchymal stem cells (BM-MSCs) differentiate into retinal neural cells in vivo and in vitro ${ }^{(14)}$, and when implanted at a site of injury in experimental animal models, they demonstrate the ability to migrate to the injury site, initiate tissue repair, and restore function ${ }^{(15-17)}$. Despite the fact that stem cells integrate into damaged retina layers and differentiate into retinal cells, there has been no evidence of restored functionality or long-term graft survival ${ }^{(18-19)}$.

The purpose of the present study was to evaluate the pattern of retinal integration and differentiation of MSCs injected into the vitreous cavity of eyes with retinal injury.

\section{METHODS}

\section{Isolation and Culture of BM-MSCS}

Bone marrow was collected from two 2-month-old isogenic Wistar rats by flushing their femurs and tibias with Dulbecco's modified Eagle's medium (DMEM; Gibco). Cells were incubated at $37^{\circ} \mathrm{C}$ and $5 \% \mathrm{CO}_{2}$ for $48 \mathrm{~h}$ and nonadherent cells were removed. The cells, fibroblast-like in shape, were grown and expanded in flasks for several weeks, and exhibited typical characteristics of MSCs.

\section{Establishment of a laser-injured model}

All experiments were performed according to the Ethics Principles in Animal Experimentation (CETEA/UFMG) and approved (certificate number 3/2006).

Wistar rats $(\mathrm{n}=18)$ were anesthetized with solution ketamine $(40 \mathrm{mg} / \mathrm{mL})$ and xylazine $(60 \mathrm{mg} / \mathrm{mL})$, injected intramuscularly. Mydriasis was induced by anesthesia; no eye- drops were used for pupillary dilation. The retinal lesion was induced by an Nd-YAG laser, using an average $0.5 \mathrm{~mJ}$ energy. A Goldmann three-mirror lens was used to produce approximately 15 to 20 YAG laser shots around the optic disc. The lesions were all full-thickness retina and choroid disruptions, as observed by deep subretinal hemorrhage and sometimes mild vitreous hemorrhage after the spot was produced. Animals in which the laser caused massive vitreous hemorrhage $(n=3)$ were not used in the study.

\section{BM-MSC labeling and viability}

After three passages, bone marrow-derived adherent cells were incubated with $50 \mu \mathrm{g} / \mathrm{mL}$ 4',6-diamidino-2-phenylindole (DAPI; Molecular Probes, Invitrogen, Carlsbad, CA) at $37^{\circ} \mathrm{C}$ and $5 \% \mathrm{CO}_{2}$ for $2 \mathrm{~h}$. BM-MSCs were treated with trypsin (Gibco) for $3 \mathrm{~min}$ to generate a single-cell suspension, washed three times with DMEM, resuspended in serum-free DMEM, counted, and stored on ice until transplantation. Fluorescence from DAPI labeling of BM-MSCs and cell viability were evaluated at $1,2,3,4$, and 8 weeks after cell labeling.

\section{Intravitreal transplantation of MSCs}

Rats (10 - 12-week-old Wistar SHR rats; $\mathrm{n}=18$ ) were anesthetized by intramuscular injection with solution ketamine (40 $\mathrm{mg} / \mathrm{mL})$ and xylazine $(60 \mathrm{mg} / \mathrm{mL})$. A cell suspension $(20 \mu \mathrm{l})$ containing approximately $4 \times 10^{5}$ DAPI - labeled BM-MSCs was slowly injected into the vitreous cavity via the pars plana using a 30 gauge needle $24 \mathrm{~h}$ after the retinal lesion was induced by the laser in 9 animals (both eyes). Three groups of animals were studied: 1) rats with retinal injury and injection of BM-MSCs ( $\mathrm{n}=9) ; 2$ ) rats with retinal injury without injection of BM-MSCs ( $=9)$; 3 ) rats without retinal injury with injection of $\operatorname{BM}-\operatorname{MSCs}(\mathrm{n}=9)$.

\section{Tissue sectioning}

The animals were sacrificed 2, 4, and 8 weeks following transplantation. The eyeball was enucleated by performing a $360^{\circ}$ limbal peritomy, isolating the extraocular muscles, and dissecting the optic nerve at the apex of the orbit. The eyes were either processed freshly (embedded in OCT compound and freshly sectioned) or fixed in Omnifix (FR Chemical Inc, Mount Vernon, NY). For both processes, slides were stained with hematoxylin/eosin, and visualized under a compound microscope to evaluate retina morphology.

\section{Immunohistochemical detection}

All Paraplast-Plus embedded blocks were cut, deparaffinized, rehydrated, and subjected to immunostaining with several antibodies specific for the retinal cells. Following blocking for $1 \mathrm{~h}$ at room temperature in phosphate buffered saline ( $0.15 \mathrm{M}$ PBS), $1 \%$ bovine serum albumin, and 2\% normal bovine serum, ocular tissue sections were exposed to primary antibodies (Table 1) overnight at $4^{\circ} \mathrm{C}$ in a moist 
chamber. Control sections were treated identically, but the primary antibody was omitted. Sections were then washed three times for $5 \mathrm{~min}$ each in $0.15 \mathrm{M}$ PBS. Secondary antibody (goat anti-rabbit and anti-mouse labeled with Alexa Fluor 488 (1:500, Molecular Probes, Invitrogen) was then applied for $1 \mathrm{~h}$ at room temperature. Sections were washed three times for 5 min each in $0.15 \mathrm{M}$ PBS. The slides were viewed under a fluorescence microscope $\left(\right.$ Olympus $^{\circledR}$, Optical sectioning microscope attached to an Axioplan imaging Apotome ${ }^{\circledR}$ apparatus, Zeiss ${ }^{\circledR}$, Germany). Colocalization of Alexa 488 - labeled primary antibodies and DAPI was assessed by superimposing separate digital images of each fluorochrome.

\section{RESULTS}

\section{BM-MSCs characteristics and transplantation}

After three passages in culture, the isolated cell population became homogeneous, showing a monolayer consisting of adherent cells displaying further traits of MSCs, including a typical fibroblast-like morphology and increased proliferation (Figure 1 Left and Right). Adhesion to the culture dish also served as a criterion to distinguish MSCs from freefloating hematopoietic cells.

\section{Incorporation and distribution of the grafted cells}

To verify the fate of BM-MSCs grafted in the laser-injured rat retina, the cells were prelabeled with DAPI and injected into the vitreous space. Retinal damage has an important role in the incorporation of transplanted cells in the retina, due to the high expression of chemoattractants by injured retinal pigment epithelium (RPE). To determine the distribution of BMMSCs in the retina, we examined the tissue 2, 4, and 8 weeks after the grafting procedure (Figure 2). The transplanted cells were incorporated in a time-dependent manner. Survival of the grafted cells was substantial in all transplanted eyes at all evaluated points. At 2 weeks, the majority of the grafted cells remained in the vitreous space (Figure 2, top, right) and at 4 weeks the cells had migrated and incorporated into the host neural retina (Figure 2, bottom left). At 8 weeks, the grafted cells were almost fully incorporated into the host neural retina; BM-MSCs were present in the outer nuclear layer, inner nuclear layer, and the ganglion cell layer (Figure 2, bottom, right).

\section{Immunohistochemical analysis and fluorescence microscopy}

Immunohistochemistry was performed on sections in which BM-MSCs were incorporated in the injured retina at 8 weeks after transplantation and in the control group to examine whether the grafted cells distributed into the retinal layers expressed retinal cell type-specific markers. The cell-type markers used were rhodopsin for rod photoreceptor cells, glial fibrillary acidic protein (GFAP) for Muller cells and astrocytes, parvalbumin for bipolar and amacrine cells, and pancytokeratin for RPE (Table 1).

Most of the DAPI-labeled cells, which we presumed to be the grafted BM-MSCs, incorporated into the outer nuclear layer (ONL) and expressed rhodopsin (Figure 3, top of the right panel), and parvalbumin (Figure 3, top middle of the right panel), suggesting their potential to differentiate into rod photoreceptors and amacrine or bipolar cells, respectively. A small subset of labeled cells in the inner retina was also labeled for the glial marker GFAP (Figure 3, bottom, middle of the right panel), suggesting that these cells possess the ability to differentiate into astrocytes and Muller cells. Some DAPI-labeled cells were also observed in the subretinal space, but they did not express any retina-associated markers at any point (Figure 3, top and middle bottom of the right panel). This finding suggests that these cells might provide a local milieu that somehow evolves with the incorporation and differentiation of the grafted cells. In the control group sections (where the injured retina did not receive BM-MSC transplants), the retina-specific markers were evident and no DAPI-labeled cells were observed, ruling out the possibility of auto-fluorescence of the retinal cells (Figure 3, left panel). There was also no co-localization of DAPI-labeled cells with the RPE-specific marker (Figure 3, bottom, right panel), suggesting that the grafted cells did not differentiate into RPE cells.

\section{DISCUSSION}

There are several sight-threatening retinal disorders for which treatment is not yet available or produces poor results. In some of these diseases, retinal degeneration occurs early in life and might be quite rapid, whereas in other disorders, retinal degeneration begins later and progresses very slowly. There are some possible sources for the repair of retinal dege-

\begin{tabular}{|c|c|c|c|c|c|}
\hline \multirow{5}{*}{ Immunohistochemistry } & Antigen & Clone & Species & Supplier & Dilution \\
\hline & Rhodopsin & [RET-P1] & $\begin{array}{c}\text { Mouse } \\
\text { monoclonal }\end{array}$ & Abcam & $1: 16$ \\
\hline & $\begin{array}{l}\text { GFAP (Glial fibrillary } \\
\text { acidic protein) }\end{array}$ & & Rabbit & Abcam & $1: 1000$ \\
\hline & Parvalbumin & & Rabbit & Abcam & $1: 1000$ \\
\hline & Pan-cytokeratin & {$[\mathrm{C}-11]$} & $\begin{array}{c}\text { Mouse } \\
\text { monoclonal }\end{array}$ & Abcam & $1: 250$ \\
\hline
\end{tabular}




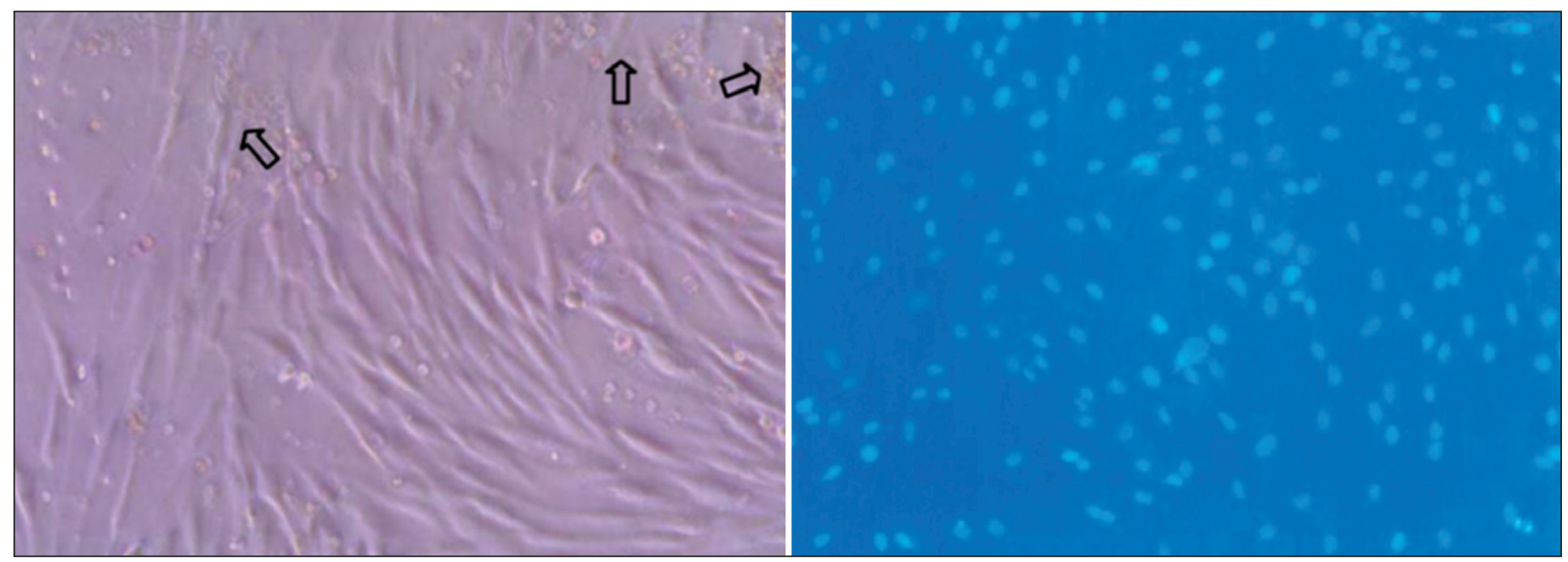

Figure 1 - Morphologic analysis of cultivated and DAPI-labeled rat bone marrow mesenchymal stem cells (BM-MSCs). (Left) Phase contrast microscopy of rat BM-MSCs in the cell culture dish at passage 3, showing a stretched fibroblastic phenotype. Arrows shows the presence of round-shaped erythrocytes and nonadherent cells. After expansion to the third passage, a monolayer of adherent, fibroblast-like cells were labeled with DAPI. (Right) Fluorescence microscopy of adherent, fibroblast-like cells labeled with DAPI. Original magnification X150.
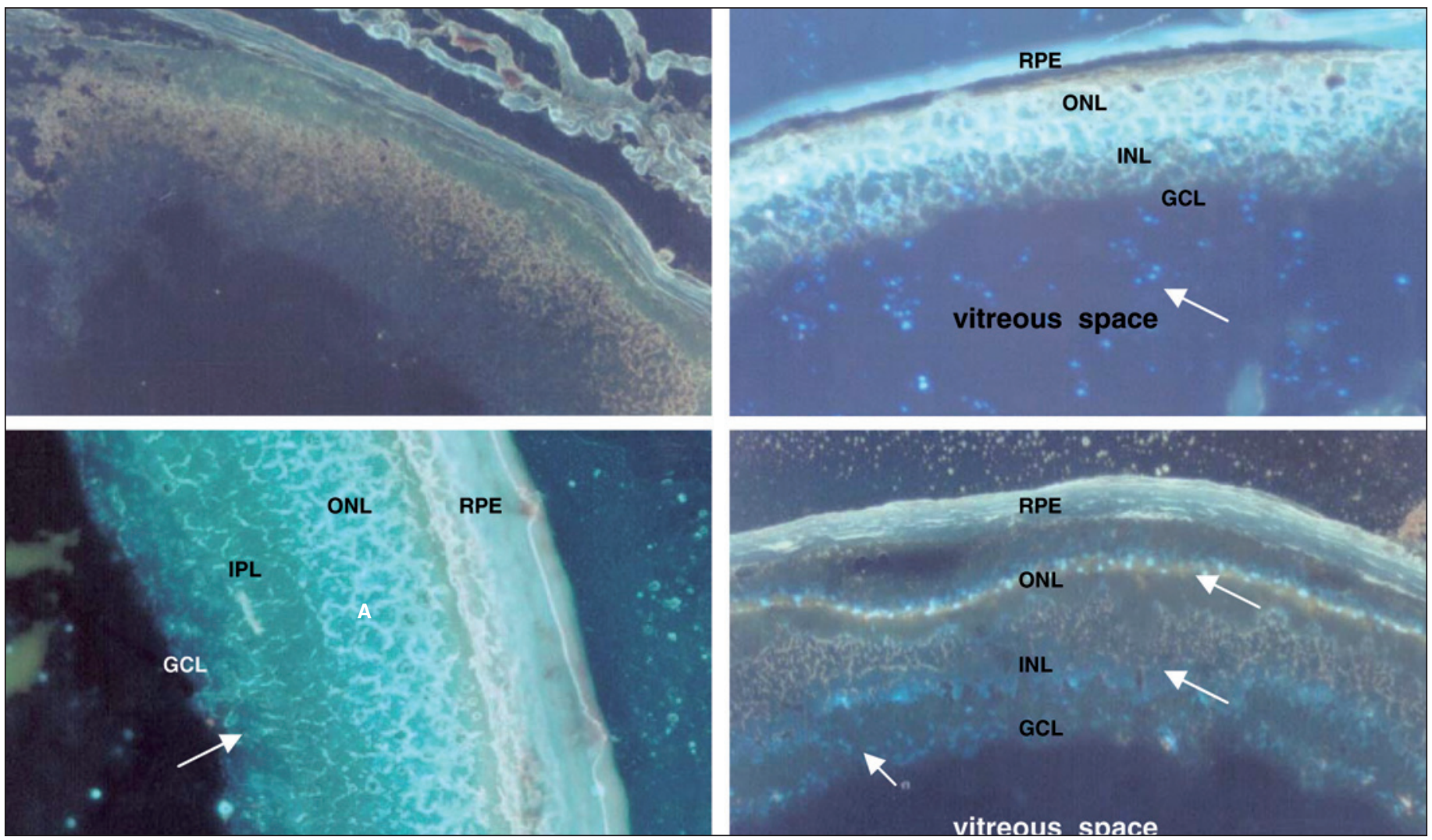

Figure 2 - DAPI-labeled BM-MSCs transplanted into the intravitreal space in rats with laser-induced damage to the retina. Distribution of the grafted cells, (top rigth) 2 weeks after transplantation, most of the grafted cells were still in the vitreous space, (bottom left) 4 weeks after transplantation, a few grafted cells incorporated into the neural retina, (bottom right) 8 weeks after transplantation, most of the grafted cells were observed in the ONL, INL, and GCL of the neural retina, (top left) control group - injured retina without BM-MSC transplantation. White arrows shows the location of the grafted cells after transplantation. Original magnification X150. RPE= retinal pigment epithelium; ONL= outer nuclear layer; INL= inner nuclear layer; GCL= ganglion cell layer

neration. A current therapeutic approach to neovascular eye diseases involves the application of angiostatic or antiproliferative agents to the eye. A cell-based therapy, however, should be explored, because, in contrast to inhibiting angiogenesis with small molecules or recombinant factors, a cellbased approach might enable the cell to adapt and respond to 


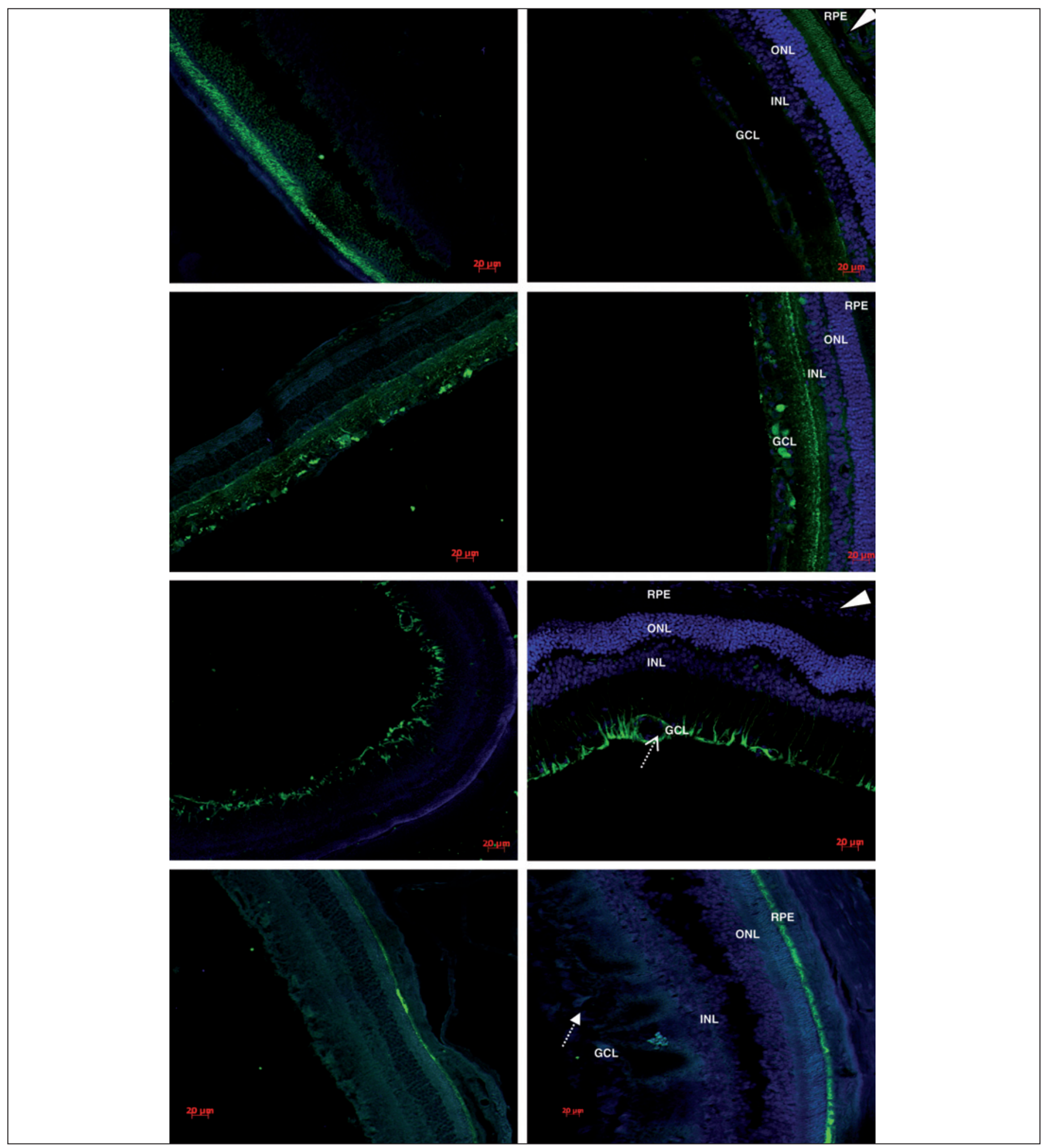

Figure 3 - Immunohistochemical detection of DAPI-labeled BM-MSCs in injured retinal sections 8 weeks after intravitreal transplantation. The left panel of each row shows immunoreactivity for a particular marker in retinal sections with laser-induced injury without BM-MSC treatment (control). The right panel of each row shows immunoreactivity for a particular marker (green) in retinal sections with laser-induced injury and BM-MSC treatment. Eight weeks after transplantation, the grafted cells labeled with DAPI (blue) co-expressed the rod photoreceptor marker (green) (top) rhodopsin, the bipolar and amacrine cell marker (green) (top middle) parvalbumin and the Muller cell and astrocyte marker (green) (bottom middle) GFAP. No grafted cells coexpressed the RPE marker (green) (bottom) pan-cytokeratin. Note that only a small subset of grafted cells was GFAP-immunoreactive (dashed arrows). Arrowheads in the right panel (top) and (bottom middle) indicate the presence of grafted cells (blue) in the subretinal space. Micrographs of the control group did not show any nonspecific labeling or fluorescence expression. Scale bars, $20 \mu \mathrm{m}$. $\mathrm{RPE}=$ retinal pigment epithelium; $\mathrm{ONL}=$ outer nuclear layer; $\mathrm{INL}=$ inner nuclear layer; $\mathrm{GCL}=$ ganglion cell layer. 
a changing environment. Cell-based therapy likely involves numerous factors produced by the cell that can be appropriately modulated in response to changing conditions ${ }^{(20)}$. It was demonstrated that MSCs are able to secrete neurotrophic factors that promote neural cell survival ${ }^{(21)}$.

The multipotentiality of BM-MSCs as well as their easy isolation and culture properties and their high expansion potential makes these cells an ideal source for autologous transplantation aimed at a cell-based therapy for retinal degeneration repair ${ }^{(2)}$.

Several studies have demonstrated the survival, incorporation, and morphologic integration of transplanted neural stem cells in injured retinas ${ }^{(22-24)}$. Few studies, however, have examined the potential of BM-MSCs to regenerate damaged retinas $^{(25)}$ injecting stem cell-enriched bone marrow cells into injured rat eyes and observed that the cells were incorporated into the host retina and that some of the CD45+ cells differentiated into retinal neural cells in vivo. MSCs can also be induced to differentiate into photoreceptors in vitro and in vivo $^{(14)}$.

Also, a recent study compared MSCs and retinal progenitor cells to evaluate their potential as a source for retinal transplantation $^{(26)}$. Both cell types expressed neuronal markers in vitro but some MSCs differentiated into cells that resembled microglia rather than neural cells. These findings suggested that retinal progenitor cells are the best choice for retinal transplantation studies, but MSCs remain an attractive candidate as a therapeutic tool for retinal repair in autologous transplantation.

In the present study, we injected BM-MSCs intravitreally into the rat eye $24 \mathrm{~h}$ after an Nd-YAG laser injury in the retina and observed that the grafted cells dispersed into the host retina and assumed different patterns of distribution. Specific antibodies were used to determine the ability of grafted MSCs to morphologically differentiate within the environment of transplanted eyes. Co-localization of DAPI with one of the specific phenotypic antibody markers was used to evaluate neural differentiation of the grafted cells. The grafted BM-MSCs incorporated into the host neural retina and expressed GFAP, rhodopsin, and parvalbumin, suggesting neural differentiation.

The presence of a subset of cells in the subretinal space suggests that these cells are accelerating the regeneration process of the retina. The stimulatory effect of BM-MSCs is related to the secretion of various neurotrophic factors that activate compensatory processes in abnormal tissues ${ }^{(27-29)}$. Also, BM-MSCs produce several matrix molecules and have a great potential to repair damage resulting from injury, ischemia, and normal aging ${ }^{(30)}$.

In addition to the used cell type, another issue to be investigated is the preferential method of transplantation of the stem cells close to the retina. There are two methods of transplantation, subretinal and intravitreal, that are widely described in the literature and both seem to be effective. The subretinal implantation of stem cells is a more demanding and complex procedure. Intravitreal injection is a more popular and a much less invasive procedure. No apparent differences in the efficacy of these cell engrafting procedures are reported in the literature, thus intravitreal injection is the best choice because it is less invasive. The vitreous body anatomy of the rat eye, however, should also be considered. The vitreous cavity in the rat eye is crescent moon-shaped, which brings the injected cells closer to the retinal surface, perhaps allowing easier access of the cells to the retinal layers.

A comparison of the incorporation of cells between the injured and non-injured groups suggested that the extent of the lesion had a role in the engrafting of the cells. The study demonstrated that the cells incorporated and differentiated in the injured group, but not in the non-injured group, as previously reported by some authors. Migration and integration of the transplanted cells into the host tissue is probably induced by its injury. According to Chacko, the widespread migration and incorporation of neural stem cells was observed only in retina that was either diseased ${ }^{(24)}$ or traumatized ${ }^{(23)}$. Those injuries could provide a local milieu (interleukins, chemotaxins, inflammatory and growth factors, etc), that is responsible for the migration and incorporation of exogenous ocular stem cells. It was recently reported that damaged RPE secretes cytokines that serve as chemoattractants for BM-MSCs by regulating the homing and migration of these cells to the injury site ${ }^{(17)}$.

The use of DAPI as a cell tracer can become a problem in transplant experiments, due to its considerable diffusion and uptake by host retinal cells. To overcome this problem, there are now some ongoing experiments, in our laboratory, using MSCs labeled with GFP.

These in vitro studies are essential to understand the process of stem cell-based therapies and allow for the evaluation of the nature of the factors responsible for the homing of these cells as well as the conditions that promote integration and differentiation of the grafted cells into the host retina. Once these issues are clear, there is a great potential for the use of stem cells in clinical therapy, but further studies are needed to ensure their safe and effective transplantation.

\section{CONCLUSIONS}

The present study demonstrated that MSCs can incorporate and differentiate into specific cellular components of the retina after laser-induced tissue injury.

\section{ACKNOWLEDGMENTS}

The authors would like to thank Gregory Thomas Kitten, $\mathrm{PhD}$ from the Morphology Department for assistance in the immunohistochemical studies and Marco Antônio Máximo 
Prado, PhD from the Pharmacology Department of the Biological Sciences Institute of the Universidade Federal de Minas Gerais, Brazil for assistance in data acquisition.

\section{RESUMO}

Objetivo: Avaliar o padrão de integração e diferenciação retiniana de células tronco mesenquimais (CTM) injetadas na cavidade vítrea de ratos portadores de lesões retinianas. Métodos: Ratos Wistar adultos foram submetidos a múltiplas lesões retinianas utilizando-se YAG laser e injeção intravítrea de células tronco mesenquimais. A fim de se avaliar a integração e diferenciação retiniana, o tecido retiniano lesado pelo YAG laser / tratado pelas células tronco, foi avaliado 2, 4 e 8 semanas após a lesão. Resultados: As células injetadas na cavidade vítrea sobreviveram na retina por pelo menos 8 semanas e quase todas células tronco mesenquimais migraram e incorporaram-se na retina neural, especificamente nas camadas nucleares externa e interna e camada de células ganglionares. Uma pequena quantidade de células foi encontrada no espaço sub-retiniano. A análise imuno-histoquímica de 8 semanas mostrou que a maioria das células injetadas expressou rodopsina (marcador para fotorreceptores), parvalbumina (marcador para células bipolares e amácrinas), GFAP (marcador de células gliais). As células injetadas não expressaram a pancitoqueratina, que é a marcadora de células do epitélio pigmentar da retina. Conclusões: Ocorre aparente diferenciação e incorporação de células tronco mesenquimais na retina de ratos após injeção intravitrea destas células.

Descritores: Células-tronco mesenquimais/fisiologia; Sobrevivência celular/efeitos de droga; Degeneração retiniana; Retina/lesões; Injeções; Corpo vítreo; Ratos

\section{REFERENCES}

1. Limb GA, Daniels JT, Cambrey AD, Secker GA, Shortt AJ, Lawrence JM, et al. Current prospects for adult stem cell-based therapies in ocular repair and regeneration. Curr Eye Res. 2006;31(5):381-90.

2. Inoue $\mathrm{Y}$, Iriyama $\mathrm{A}$, Ueno $\mathrm{S}$, Takahashi $\mathrm{H}$, Kondo $\mathrm{M}$, Tamaki $\mathrm{Y}$, et al. Subretinal transplantation of bone marrow mesenchymal stem cells delays retinal degeneration in the RCS rat model of retinal degeneration. Exp Eye Res. 2007;85(2):234-41.

3. Vemuganti GK. Can we grow new retina? Community Eye Health J. 2006; 19(57):6-8.

4. Kan I, Melamed E, Offen D. Autotransplantation of bone marrow-derived stem cells as a therapy for neurodegenerative diseases. Handb Exp Pharmacol. 2007;(180):219-42.

5. Javazon EH, Beggs KJ, Flake AW. Mesenchymal stem cells: paradoxes of passaging. Exp Hematol. 2004;(32):414-25.

6. Zuk PA, Zhu M, Mizuno H, Huang J, Futrell JW, Katz AJ, et al. Multilineage cells from human adipose tissue: implications for cell-based therapies. Tissue Eng. 2001;(7):211-28.

7. Jaiswal N, Haynesworth SE, Caplan AI and Bruder SP. Osteogenic differentiation of purified, culture-expanded human mesenchymal stem cells in vitro. J Cell Biochem. 1997;64(2):295-312.

8. Yoo JU, Barthel TS, Nishimura K, Solchaga L, Caplan AI, Goldberg VM, et al. The chondrogenic potential of human bone-marrow-derived mesenchymal progenitor cells. J Bone Jt Surg Am. 1998;80(12):1745-57.

9. Wakitani S, Saito T, Caplan AI. Myogenic cells derived from rat bone marrow mesenchymal stem cells exposed to 5-azacytidine. Muscle Nerve. 1995;18(12):1417-26.

10. Pittenger MF, Mackay AM, Beck SC, Jaiswal RK, Douglas R, Mosca JD, et al. Multilineage potential of adult human mesenchymal stem cells. Science. 1999;284:143-7.

11. Mezey E, Chandross KJ, Harta G, Maki RA, McKercher SR. Turning blood into brain: cells bearing neuronal antigens generated in vivo from bone marrow. Science. 2000;290(5497):1779-82. Comment in: Science. 2000;290(5497): 1672-4.

12. Woodbury D, Reynolds K, Black IB. Adult bone marrow stromal stem cells express germline, ectodermal, endodermal, and mesodermal genes prior to neurogenesis. J Neurosci Res. 2002;69(6):908-17.

13. Lu D, Li Y, Wang L, Chen J, Mahmood A, Chopp M. Intra-arterial administration of marrow stromal cells in a rat model of traumatic brain injury. $\mathrm{J}$ Neurotrauma. 2001;18(8):813-9.

14. Kicic A, Shen WY, Wilson AS, Constable IJ, Robertson T, Rakoczy PE. Differentiation of marrow stromal cells into photoreceptors in the rat eye. J Neurosci. 2003;23(21):7742-9.

15. Pittenger MF, Martin BJ. Mesenchymal stem cells and their potential as cardiac therapeutics. Circ Res. 2004;95(1):9-20.

16. Barbash IM, Chouraqui P, Baron J, Feinberg MS, Etzion S, Tessone A, et al. Systemic delivery of bone marrow-derived mesenchymal stem cells to the infarcted myocardium: feasibility, cell migration, and body distribution. Circulation. 2003;108(7):863-8.

17. Li Y, Reca RG, Atmaca-Sonmez P, Ratajczak MZ, Ildstad ST, Kaplan HJ, et al. Retinal pigment epithelium damage enhances expression of chemoattractants and migration of bone marrow-derived stem cells. Invest Ophthalmol Vis Sci. 2006;47(4):1646-52.

18. Tsonis PA, Del Rio-Tsonis K. Lens and retina regeneration: transdifferentiation, stem cells and clinical applications. Exp Eye Res. 2004;78(2): 161-72. Review.

19. Klassen H, Sakaguchi DS, Young MJ. Stem cells and retinal repair. Prog Retin Eye Res. 2004;23(2):149-81. Review.

20. Friedlander M. Fibrosis and diseases of the eye. J Clin Invest. 2007;117(3): 576-86.

21. Chen Q, Long Y, Yuan X, Zou L, Sun J, Chen S, et al. Protective effects of bone marrow stromal cell transplantation in injured rodent brain: synthesis of neurotrophic factors. J Neurosci Res. 2005;80(5):611-9.

22. Wojciechowski AB, Englund U, Lundberg C, Warfvinge K. Survival and long distance migration of brain-derived precursor cells transplanted to adult rat retina. Stem Cells. 2004;22(1):27-38.

23. Nishida A, Takahashi M, Tanihara H, Nakano I, Takahashi JB, Mizoguchi $\mathrm{A}$, et al. Incorporation and differentiation of hippocampus-derived neural stem cells transplanted in injured adult rat retina. Invest Ophthalmol Vis Sci. 2000;41(13):4268-74

24. Young MJ, Ray J, Whiteley SJ, Klassen H, Gage FH. Neuronal differentiation and morphological integration of hippocampal progenitor cells transplanted to the retina of immature and mature dystrophic rats. Mol Cell Neurosci. 2000;16(3):197-205.

25. Tomita M, Adachi Y, Yamada H, Takahashi K, Kiuchi K, Oyaizu H, et al. Bone marrow-derived stem cells can differentiate into retinal cells in injured rat retina. Stem Cells. 2002;20(4):279-83.

26. Tomita M, Mori T, Maruyama K, Zahir T, Ward M, Umezawa A, Young MJ. A comparison of neural differentiation and retinal transplantation with bone marrow-derived cells and retinal progenitor cells. Stem Cells. 2006; 24(10): 2270-8.

27. Li Y, Chen J, Chen XG, Wang L, Gautam SC, Xu YX, et al. Human marrow stromal cell therapy for stroke in rat: neurotrophins and functional recovery. Neurology. 2002;59(4):514-23. Comment in: Neurology. 2002;59(4):486-7.

28. Mahmood A, Lu D, Chopp M, Marrow stroma cell transplantation after traumatic brain injury promotes cellular proliferation within the brain. Neurosurgery. 2004;55(5):1185-93.

29. Crigler L, Robey RC, Asawachaicharn A, Gaupp D, Phinney DG. Human mesenchymal stem cell subpopulations express a variety of neuro-regulatory molecules and promote neuronal cell survival and neuritogenesis. Exp Neurol. 2006;198(1):54-64.

30. Le Blanc K, Ringdén O. Immunobiology of human mesenchymal stem cells and future use in hematopoietic stem cell transplantation. Biol Blood Marrow Transplant. 2005; 11(5):321-34. 